\title{
THE TERRITORIAL IMPACTS OF JESSICA PROJECTS IN MUNICIPALITIES: EVIDENCE FROM THE CITY OF POZNAN'***
}

\section{INTRODUCTION}

Although cities tend to grow over time and are generally considered as a driving force of the modern socio-economic development of regions and countries, they do not grow uniformly, especially when one takes into account the spatial dimension of their development. This concerns not only the significant differences noticeable in the level of their growth rates in the last decades but also pertains to the serious threat of economic stagnation or decline brought about by spatial polarization and segregation processes in their inner areas. ${ }^{1}$ Since European cities face very serious challenges and the public possibilities of spending to address the structural needs remain constrained, the European Commission introduced the JESSICA initiative (Joint European Support for Investments in City Areas) in the years 2007-2013, as a part of the EU Cohesion Policy. JESSICA constitutes an alternative to the traditional assistance provided in the form of grant-based funds. It aims at supporting sustainable urban development in a repayable and recyclable way. This means that JESSICA promotes economically viable projects through the use of the repayable financing mechanism. This innovative financial instrument could potentially play a critical role in accelerating further investments in disadvantaged urban areas. This area, however, is not well investigated and only a few studies have been conducted that provide evidence on the functioning of

* Piotr Idczak, Poznań University of Economics and Business, piotr.idczak@ue.poznan.pl, https://orcid.org/0000-0002-3754-8956.

** Karol Mrozik, Poznań University of Life Sciences, karol.mrozik@up.poznan.pl,https://orcid.org/0000-0003-2169-5430.

*** The study was supported by the National Science Centre, Poland (no. 2015/19/D/ HS5/01561).

1 Budde et al. (2010); Colini et al. (2013). 
the JESSICA's institutional framework and demonstrating its importance for the transformation of urban areas. ${ }^{2}$ Furthermore, there are only a few other studies that substantiate the repayability of JESSICA funding and its ability to spark market processes in cities. ${ }^{3}$

While the aforementioned literature highlights the importance of JESSICA's action mechanism, and to some extent also its outcomes, less attention has been paid to the territorial impacts of JESSICA projects on urban areas. Thus, the question is whether these projects have contributed to improving the territorial cohesion in urban areas. To date, the problem has received scant consideration in the economic research literature. This paper seeks to fill this gap in the context of the integrated approach, which requires the close coordination of measures promoting good territorial governance to ensure sustainable urban development. Therefore, the objective of this research is to examine the territorial impacts of JESSICA projects through providing evidence on the significance of the outcomes and changes brought about by these projects in Poznań's urban areas. For the purpose of examination, a TIA tool (TARGET_TIA) was applied, since it is the most complete and adequate existing technique that takes into account all the dimensions of territorial cohesion.

By doing this, the study makes several noteworthy contributions to the literature on EU Cohesion Policy and sheds more light on the use of the repayable instruments within public interventions, while providing, for the first time, a critical analysis of JESSICA project impacts from the territorial perspective, which is especially relevant for supporting sustainable urban development.

\section{URBAN DEVELOPMENT AND TERRITORIAL COHESION}

Cities create solutions as well as problems. For centuries, they have been the focal points for consumers, workers and businesses, centres of innovation and culture, and also the birthplace for some of humankind's greatest ideas. All of these characteristics, together with formal and informal institutions, create the potential to produce externalities and increasing returns to scale. A concentration of growth factors and activities allows existence of agglomeration economies that enhance productivity and contribute to the emergence of new businesses and job creation which, as a consequence, become the basis for the urban development of cities. ${ }^{4}$ However, the same market forces that make a city 'thick', cohesive and successful also give rise to intra-urban inequalities and socio-economic polarization. ${ }^{5}$ The contradictive effects of urban economies, known as diseconomies of agglomeration, appear when the continuously grow-

\footnotetext{
2 Bode (2015); Dąbrowski (2014); Fotino (2014); Nadler, Nadler (2018).

${ }^{3}$ Idczak, Musiałkowska (2019); Idczak, Musiałkowska, Mrozik (2019); Musiałkowska, Idczak (2018).

${ }^{4}$ Camagni, Capello, Caragliu (2015); Henderson (2000).

${ }^{5}$ Castells-Quintana Royuela (2014); Duranton, Kerr (2018); Glaeser (2010).
} 
ing city gets to a point at which agglomeration factors do not support economic growth and make a particular location less attractive. The diseconomy forces become sufficient enough to create a pattern of spatially unbalanced urban growth. Consequently, some inner urban areas emerge that are vulnerable to cumulative risks. From Myrdal's theory of cumulative causation, which sought to explain the spatial imbalances in the economy and spatially uneven development, ${ }^{6}$ through the 'new' economic geography of Krugman, where a mix of economies of scale, specialization and transport costs are used to clarify the growth of urban areas, ${ }^{7}$ to the place-based approach proposed by Barca, who traces underdevelopment in some places to the lack of a tailored policy response to the location-specific needs ${ }^{8}$ it is certain that these agglomeration diseconomies can be tackled through the place-adjusted public interventions addressing the tendencies towards urban inequalities.

From this perspective, the implication is that the territorial dimensions of urban development cannot be ignored. Furthermore, it should be seen as an indispensable element of urban development, requiring that particular attention must be paid to the impact of programmes and projects in terms of promoting spatially balanced, harmonious and sustainable development. Drawing upon Faludi's territorial cohesion thinking, ${ }^{9}$ it is argued that intervention measures designed for urban areas should acquire an added value by forming coherent policy packages which take into account the specific opportunities and constraints of a given place. More substantively, such an approach strives to provide a more cohesive and balanced territory through reducing socio-economic territorial imbalances, promoting environmental sustainability, improving the territorial governance processes and, fundamentally, reinforcing a more polycentric urban system. ${ }^{10}$ In that respect, urban measures have to provide a trade-off between people- (sectoral-) and area-based interventions in order to, one the one hand, preserve the original social characteristics of a particular area and, on the other, to carry out in-depth physical upgrading and restructuring with the main goal of combating a variety of problems in deprived areas. This, however, requires horizontal, vertical and territorial integration, ${ }^{11}$ otherwise the implementation of urban measures will remain effectively irrelevant. The integration of various policy measures in a local area, which has to be embedded into higher (regional and higher) level polices and made under the conditions of multi-level governance, enables the

${ }^{6}$ Myrdal (1957).

${ }^{7}$ Krugman (1991).

${ }^{8}$ Barca, McCann, Rodríguez-Pose (2012): 137-141.

${ }^{9}$ Faludi (2009).

${ }_{10}$ Medeiros (2016): 10; (2019): 3-11.

${ }^{11}$ In the literature, horizontal integration is generally understood to mean establishing and coordinating the policy fields in a specific area. Vertical integration refers to bringing policies from different levels of government together. In turn, territorial integration tends to be used to refer to reshaping functional areas to make them evolve into a consistent geographical entity in which policy interventions are not limited only to deprived neighbourhoods, but constitute an inherent part of development policies for the entire entity. For more see Böhme et al. (2011): 23-28; Ramsden (2011): 53-56. 
creation of a joint territorial development policy. ${ }^{12}$ The important role played in this complex process by the integrated approach is key to ensuring a greater complementarity and synergy between various urban measures designed to counteract multiple deprivations. Sound urban programmes and projects must therefore shape a form of urbanization which provokes a desirable territorial cohesion path that runs counter to common patterns of territorial development and trends.

\section{JESSICA INITIATIVE}

The JESSICA initiative was introduced to promote sustainable urban development projects through using financial engineering instruments as an economic stimulus, on a revolving basis - as a real counterweight to the currently predominant grant-based assistance. The revolving financing mechanism means that the capital provided can be reinvested in new projects, thus enabling the 'recycling of funds' and produce an acceleration of further investments in disadvantaged urban areas. ${ }^{13}$ The initiative has employed the use of financial assistance available under one of the structural funds - the European Regional Development Fund. Moreover, it also brought new actors into the policy-making process because a new scope for a shift has arisen not only in the governance of Cohesion Policy but also in general governance styles and practices at other decision levels. ${ }^{14}$ JESSICA laid down a requirement to ensure the planning of urban actions and projects by many entities, namely: regional managing authorities (MA) responsible for designing the scope of operational programmes, the European Investment Bank (EIB) - being a so-called holding fund for the JESSICA allocations, Urban Development Funds (UDFs) - mainly private or semi-public institutions such as banks, in Poland there were: Bank Ochrony Środowiska, Bank Zachodni WBK S.A., Bank Gospodarstwa Krajowego, and local authorities that are the main stakeholder interested in solving the problems associated with degraded urban areas. Together with the EIB, UDFs introduced the elements of risk assessment and the market approach to public intervention projects, and local authorities, in turn, were in charge of the delimitation of regeneration areas in the cities, that is to identify urban areas requiring the most support. ${ }^{15}$ Along these lines, it is relevant to note that although the repayable forms of assistance pose the great organizational challenges for both private and public sides, they prioritize more market-tailored projects, thus stimulating further investments in cities. ${ }^{16}$

12 Tosics (2015): 2-7.

13 Nyikos (2016): 15-24.

14 Dąbrowski (2014): 2007.

15 For more see Musiałkowska, Idczak (2020): 172-182.

16 This is evident in studies on the 2014-2020 period carried out by Nyikos (2016): 63-64, and Béres et al. (2019). 
In general, the urban projects executed under the umbrella of JESSICA were expected to render positive externalities for urban inhabitants, particularly in areas having substantial needs for a long period. They should aim at reducing negatives states and contributing to an increase in the quality of the life and work of citizens. Since the EU Cohesion Policy also reinforces the urban dimension, all projects planned to be implemented under the JESSICA initiative had to be included in an integrated plan for sustainable urban development (IPFSUD). By establishing such a plan, the municipalities provided a comprehensive response to the diagnosed urban challenges and the needs that had to be addressed, and specifically those requiring mitigating measures. In this respect, IPFSUD had to specify 'a system of interconnected measures designed to produce a permanent improvement in the economic, physical, social and environmental conditions of a city or quarter' ${ }^{17}$ Hence, it is clear that urban projects need to be comprehensive as such - that is, tailored to local needs, combining various aspects on a case-by-case basis: economic development, social integration, education, culture, environmental issues, spatial planning... etc. In this way, through the effects of synergy, they should contribute to achieving the IPFSUD's objectives.

In a nutshell, JESSICA projects should incorporate all the driving factors essential for sustainable urban development and take account of urban problems in a coordinated way so as to be sustainable for themselves and for the entire city. ${ }^{18}$ Following this line of reasoning, the paper seeks to examine the contribution of JESSICA projects to improving the territorial cohesion of urban areas.

\section{Data and research methods}

The study makes use of two separate data sources, one for mapping JESSICA projects and depicting their overall spatial relationships; the other to identify the territorial impacts of JESSICA projects on urban areas. For the former, we use a personally compiled database of JESSICA projects implemented in Poznań during the 2007-2015 period. The essential part of the data originated from the Marshall Offices of the Wielkopolska region. Since the data were of a general nature and did not exhaust the needs of the study, additional records were obtained from other sources. For instance, the data on the location of projects were acquired as a result of an in-depth analysis of commonly available descriptions of all JESSICA projects, including information widely available on the Internet. This in turn made it possible to undertake geocoding and thus to determine the latitude and longitude coordinates of projects. The remaining data come from the examination of other sources (multiple online resources), such as project descriptions, policy reports, and field studies, but also were obtained by the participant-observation method

\footnotetext{
17 Urbact (2010): 37.

18 Nadler, Nadler (2018): 1843.
} 
and interviews. The source material collected in this way was properly edited, processed and entered into the database in the form of statistical variables.

As for the second data source on territorial impacts, it is based on the judgements of experts. As is well known, the main challenges that territorial impact assessment has to face is the difficulty of measuring the effects of intervention. We address this problem through linking expert knowledge and judgements about the impact with the data from our database describing the characteristics of JESSICA projects. By doing so, we gathered reliable and robust information which serves as input for the impact analysis and facilitates the interpretation of the output indicators of the impact assessment. A complete account of the survey evidence is provided in the supplemental data online ${ }^{19}$.

In order to extract meaningful information on the territorial impacts of JESSICA projects on urban areas, we used the territorial impact assessment methodology (TIA). It has been devised to be applied in the EU to enable the identification and evaluation of actual or potential territorial impacts in relation to concrete projects, programmes or policies at national, regional and local levels. ${ }^{20}$ The analysis includes all nine JESSICA projects implemented in the city of Poznan. The main criterion for the choice of the city for the purpose of this study was simple - (i) first, Poznań was a city with a relatively high number of JESSCA projects out of all the JESSICA regions; (ii) second, it was possible to gather sufficient information and data on projects; (iii) third, there was a chance to select and mobilize experts needed for qualitative judgments.

In the study, the assessment was based on the conceptual framework proposed by Medeiros,${ }^{21}$ known as TARGET_TIA. A major advantage of this approach is that it provides more robust TIA procedures and techniques. To put it more precisely, TARGET_TIA uses a wider and more holistic set of data and is distinguished by the adaptability to each geographical scale. It allows for assessing the ex-post impacts of a given project in a given territory and for being tailor-made to a specific evaluation context. Therefore, in order to properly assess the territorial impacts of the JESSICA project on an urban area, we used TIA dimensions and components designed for urban areas (i.e. economic, social, environmental, governance and spatial planning). ${ }^{22}$ It is also necessary to add that the methodology introduced here refers to TARGET_TIA, however, it was modified by being limited to the use of a participatory and qualitative TIA approach. ${ }^{23}$ For the purpose of analysis, fourteen subject domain experts were invited, from the fields of spatial and urban planning, urban regeneration, architecture, socio-economic geography, and economics. The rules for the selection of independent experts covered not only their knowledge and profes-

${ }_{19}$ Supplemental data for this article can be accessed at <http://dx.doi.org/10.17632/rysmc2pmhs.1>.

20 For more see ESPON (2012).

21 Medeiros (2014): 50-101.

22 Medeiros (2014): 102-104.

${ }^{23}$ A major problem with quantitative information was that it was difficult to separate impacts caused by the assessed projects from those induced by many other projects, in particular when the number of JESSICA projects under study is relatively low. 
sional experience of the research subject under study, but also their ability to conduct an objective, correct fact-finding and intuitive-logical analysis of the impact of JESSICA projects on urban areas with ordinal assessments, so as to obtain quantitative assessment of experts' judgments that cannot be directly measured. To this end, a questionnaire was drawn up and sent to all of the experts. The questionnaire was designed in such a way that the particular components of the urban area TARGET_TIA dimensions were described in the form of closed-ended questions. They structured the possible answers by allowing responses which fit into TRAGET_TIA criteria determining the degree of impact. In addition, all the experts invited to the survey were provided with descriptions of JESSICA projects, including their initial assumptions and final achievements, so that they were able to carefully analyse and properly assess their impacts. In the end, ten experts returned the completed questionnaires. Bearing all this in mind, one may argue that the study provides a sufficient array of information stemming from a process that represents a shared perception of a reality, which, in this case, relates to a given state of affairs reflecting impacts of individual JESSICA projects.

\section{Main results and discussion}

This section presents the key findings from the assessment of the territorial impact of JESSICA on urban areas in Poznan in the light of economic, social, environmental, governance and spatial planning-related aspects. Prior to analysing the data, it was important to investigate the location of projects within the urban area of the city. Interestingly, as is apparent from Figure 1, eight out of nine JESSICA projects are located in the area of the city centre (śródmieście). This is of particular importance because the Urban Regeneration Programme for the city of Poznań identifies śródmieście as a specific area of concern due to 'a particular concentration of socio-economic problems of its citizens'. ${ }^{24}$ It suffers from high levels of unemployment and poverty, a high crime rate, and low levels of entrepreneurial activity. Śródmieście has become a deprived urban area which hinders investment activity and development. However, JESSICA projects could be implemented in accordance with the guidelines applicable at that time in dysfunctional urban areas delimited by at least one regeneration criterion. In practice, this means that in Poznan JESSICA projects could be executed in an area covered by criterion 1, as illustrated in Figure 1. Despite this, almost all the projects that received JESSICA loans were located in the area characterized by the highest concentrations of negative phenomena. ${ }^{25}$ In this context, all JESSICA projects should be undoubtedly viewed in a positive light.

${ }^{24}$ URPofP (2013): 32.

${ }^{25}$ It should be added that the location of a project in a problem area designated by regeneration criteria was an essential condition to obtain a JESSICA loan. The decisive criterion, however, was the project's capacity to ensure the repayability of JESSICA funding. For more on this, see Idczak, Musiałkowska (2019). 


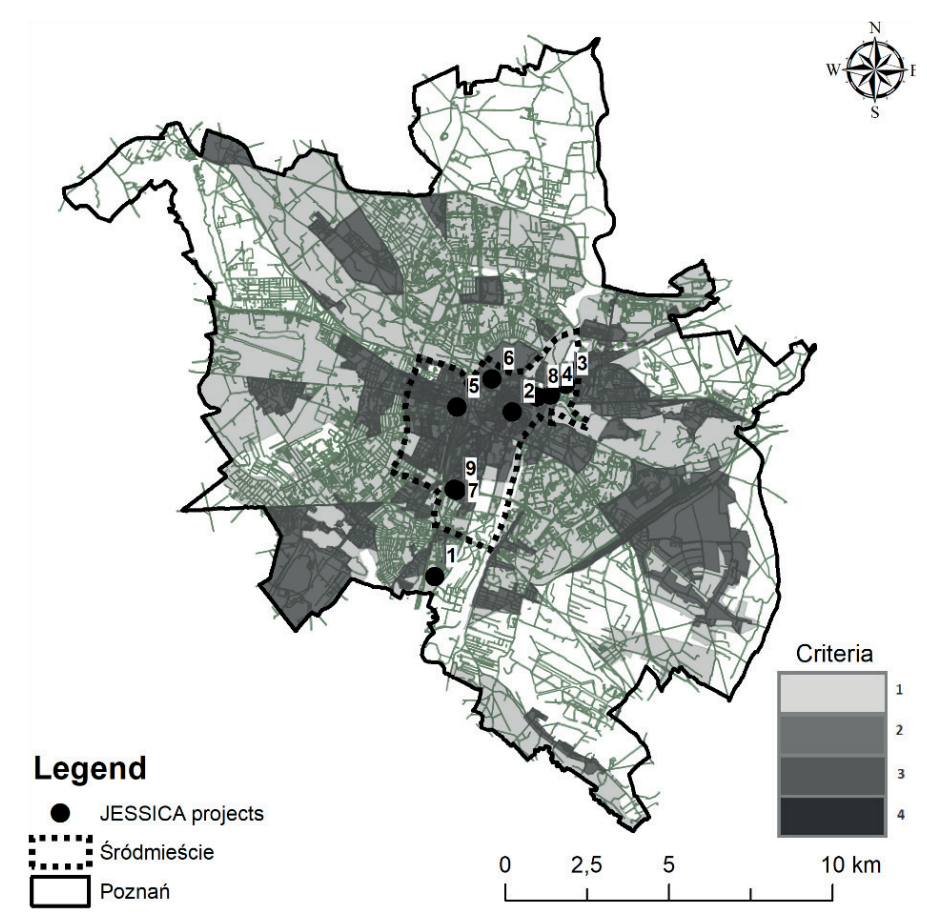

Figure 1. The location of JESSICA projects in Poznań

Source: the authors' own elaboration.

Moving on to discuss the results of the assessment of the territorial impact of JESSICA projects, Table 1 shows that not all the projects fully comply with the territorial cohesion approach to counteract various forms of urban deprivation. What is interesting about the data in this table is that two projects clearly stand out from the others in terms of the value of the territorial impacts indicator (TIM). These are the parking lot (project 2) and the hotel (project 4) located in the Śródka district. At first glance, such a result might come as a surprise. However, closer inspection of the data shows that these projects were rated highly in all assessment areas. A reasonable explanation for this outcome is that these projects, through their comprehensiveness, were able to fill the existing socio-economic gap and overcome the extensive market failures, and consequently effectively meet the special needs of particular locations. For instance, project 2 resulted in the creation of, one the one hand, a four-level underground car park, which led to the improvement of the parking system in the city centre, and on the other, modern infrastructure for commercial-office activities intended for public and private entities, but most of all for civic organizations. The project's added value brought about the formation of the new functions notably as regards the historical value of the Kolegiacki Square (it was just a car park earlier) and innumerable social effects attained 


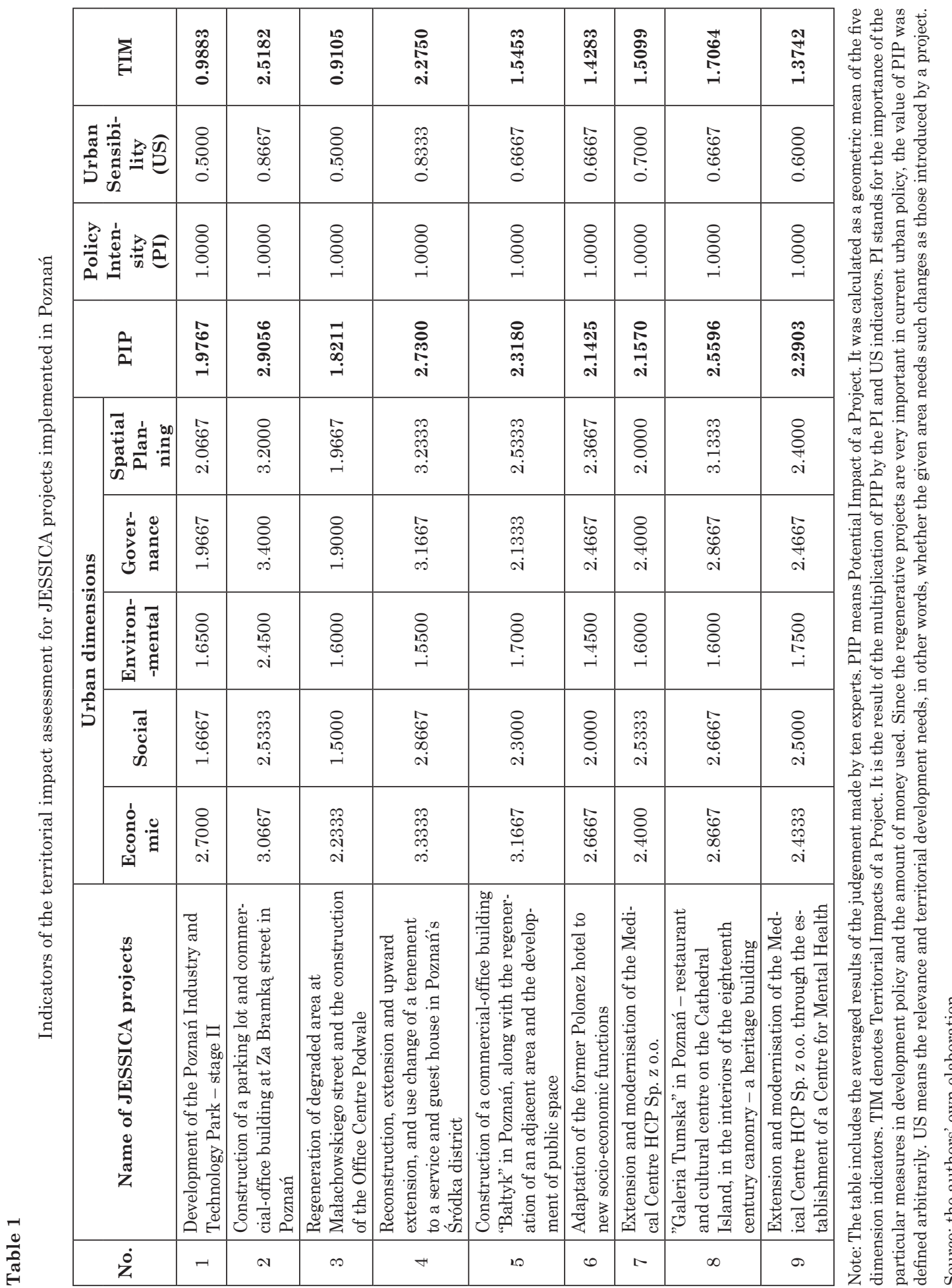


as a result of charity and support foundations based in the building. Project 4, in turn, relied on the reconstruction and adaptation of an old tenement house to hotel functions. It is important to mention that this undertaking took place right in the historic market square of the Śródka district. ${ }^{26}$ In fact, the renewal of this building allowed not only the historic urban tissue of this district to be preserved, and an architecturally harmonious whole to be formed through the improvement of public spaces, but also resulted in the introduction of new functions that create favourable conditions for growth. In addition, the project included a strong social component which, considering the needs of the Śródka area, was of great significance. Specifically, a new restaurant was established in a building that operates as social cooperative. The restaurant staff consists of people who have returned to the labour market after taking part in social and professional reintegration programmes. Thus, it promotes social inclusion and gives a real chance to improve the people's lives. The results obtained from the analysis of TIM can be compared in Figure 2 .

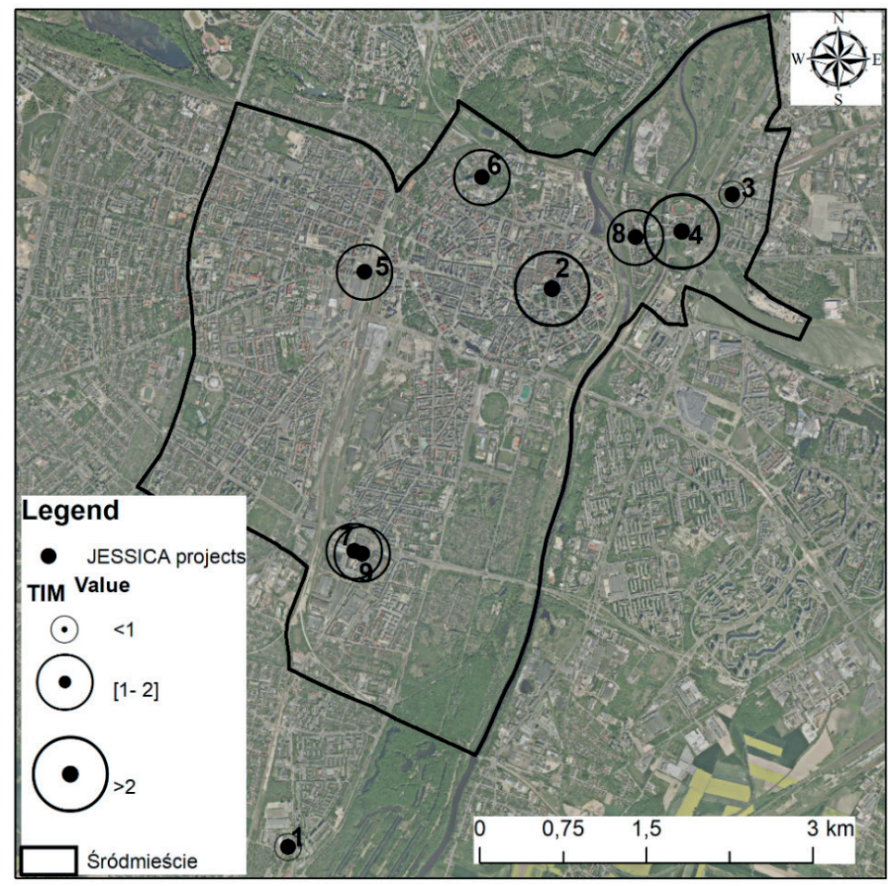

Figure 2. The territorial impacts of JESSICA projects in Poznań

Source: the authors' own elaboration.

${ }^{26}$ It is necessary here to clarify exactly that the Śródka area, although it is the oldest district of the city, was for a long time one of the most deprived areas in Poznań. It was a zone riddled with poor housing, blighted by unemployment, and socially excluded from other more prosperous districts. 
As far as the other JESSICA projects are concerned, one can see that their TIM values do not deviate from the average level for the whole project. Nevertheless, one important observation should be made regarding their potential impact values (PIP) which in all cases are significantly higher than TIM values. One might simply even say that the territorial impacts of JESSICA projects measured through the lens of PIP provide a satisfactory level of the desired added value in deprived urban areas in Poznan. PIP, however, does not take into account the policy intensity (PI) and urban sensibility (US). Admittedly, while IP does not affect the PIP values, US alters them significantly, so that the TIM values differ remarkably from them. In this respect, it appears clear that the scopes of those projects do not fully comply with the diagnosed requirements and needs of particular urban areas. This does not mean that those projects are inappropriate and do not respond inherently to the main challenges facing the particular deprived urban areas. Especially since all of them have played an important role in overcoming structural barriers and stimulating social, cultural and business activities in their locations. But the projects rated lower do not entirely meet the essential assumptions of the integrated territorial approach, in the strictest sense of this term. By way of illustration, Galeria Tumska in the Cathedral Island enabled the renovation of the heritage building and the creation of a restaurant and a cultural centre, the Bałtyk building provided a modern office and relaxation spaces, as well as a publicly accessible 'bay of art' courtyard made in formerly underused areas, and Medical Centre HCP Sp. z o.o. expanded the scope of the health services (some of them were previously unavailable) by means of a modernization and extension of its building. The reason for the unsatisfactory territorial impacts of these projects becomes clear when looking at their US values. The lower US values imply that the activities under the scope of these projects are not, according to the experts' judgement, as relevant as they could be to the specific needs of the particular urban areas.

Although the projects, throughout their economic and non-economic activities, create local benefits or help spread the benefits accruing from them, they do not take a full advantage of the territorial approach which stresses there should be a deep anchorage in the specificity of a given territory. Hence, the contributions of these projects to mitigating social, economic and environmental decline may not be totally effective, and some diagnosed problems of individual areas may remain unresolved and could hamper a balanced implementation of the entire urban regeneration programme.

However, Table 1 also reports two projects that were assessed as being well below the average level, namely, the Poznan Industry and Technology Park (project 1) and the Office Centre Podwale (project 3). Both projects aimed at stimulating the emergence of new businesses, and with the former, located outside śródmieście, also by a way of incubating. Their relatively low TIM values do not only arise from the medium levels of UP indicators but also from the lower level of the sub-indicators describing particular urban dimensions. They poorly reflect the specific needs of their location and thus their contribution to resolving the social problems and environmental issues was also 
judged as unsatisfactory. This means that projects focused mostly on boosting only the creation of new business have a significantly smaller impact on deprived urban areas and thus do not effectively address the challenges of these less-favoured areas.

With all this in mind, these results allow for the conclusion that the territorial impacts of JESSICA projects were generally positive, and only two projects were rated as low. It also means that all of the analysed projects have contributed to enhancing the territorial cohesion of the urban areas of the city of Poznań. Nonetheless, their impacts are quite varied. The main reason for these relatively interesting results is that some of them were not sufficiently well-tailored to the specific needs of the particular urban areas. A possible explanation for this might be the fact that one of the decisive criteria for granting a JESSICA loan is repayability. Thus, the Urban Development Bank, which is an official body responsible for distributing JESSICA funds, may be more willing to provide JESSICA loan to projects that display higher profitability and repayment security than those with well-designed scopes of activities.

\section{CONCLUSIONS}

This paper constitutes an attempt to examine the territorial impacts of JESSICA projects on urban areas. The research conducted here sought to determine whether these projects have contributed to improving the territorial cohesion within urban areas of Poznań.

The evidence from the TARGET_TIA application revealed a variety of socio-economic environmental and governance- and spatial planning-related territorial impacts induced by the implementation of JESSICA projects in Poznan. The initial finding of the study indicates that almost all the projects (with one exception) were situated in the area of the city centre ('śódmieście), that is, according to the Urban Regeneration Programme for the city of Poznan, the area characterized by the highest levels of deprivation and the greatest concentration of socio-economic problems. Considering that under the JESSICA initiative principles the projects could be implemented, in fact, over the two thirds of the area of Poznan and had to ensure a certain level of profitability, it can be stated that those rather economically demanding projects succeeded in dealing with the structural problems of less-favoured urban areas. Indeed, this outcome clearly demonstrates that repayable supportive instruments can be effectively applied to overcome the market failures in urban areas. It must however be borne in mind that the territorial impacts of particular projects remain uneven. The most significant finding to emerge from the TIA results is that the greatest territorial impacts are generated by those projects that best respond to the specific needs of particular deprived areas of the city. The more multiple and complex JESSICA projects are in relation to an individual urban area, the more they contribute to the improvement of the territorial cohesion of urban areas. This means that projects fulfilling the requirements of territo- 
rial (integrated) perspectives of urban development, to the maximum possible extent, make the most efficient use of JESSICA funding.

The paper provides the first territorial impact assessment of JESSICA projects implemented within the financial perspective 2007-2013. However, the generalizability of these results is subject to certain limitations because the research was restricted to the projects implemented in only one city, namely, Poznań. Notwithstanding, these results seem to be consistent with other research which found that those kinds of JESSICA projects covering a comprehensive range of services or goods are able to assure the complexity of urban development and, consequently, enhance urban sustainability. ${ }^{27}$ This allows us to substantiate the findings and consider them in a wider perspective. Nevertheless, this does not alter the fact that further works could incorporate other JESSICA projects (in other cities) and allow more in-depth knowledge of effects in urban areas.

All in all, it may be concluded that the results concerning the impacts of JESSICA projects on urban areas point to their positive contribution to improving the urban cohesion of a city. This study also suggests that the complexity of JESSICA projects (generally understood to mean compliance with socio-economic environmental and governance- and spatial planning-related dimensions) should have a higher priority when granting a JESSICA loan. This is a very important message for those involved in policy-making procedures.

Barca, F., McCann, P., Rodríguez-Pose, A. (2012). The case for regional development intervention: place-based versus place-neutral approaches. Journal of Regional Science 52(1): 134-152. doi:10.1111/j.1467-9787.2011.00756.x

Béres, A., Jablonszky, G., Laposa, T., Nyikos, G. (2019). Spatial econometrics: transport infrastructure development and real estate values in Budapest. Regional Statistics 9(2): 1-17. doi:10.15196/RS0902

Bode, M. (2015). Financial instruments in cohesion policy. European Structural and Investment Funds Journal 3(3): 173-186.

Böhme, K., Doucet, P., Komornicki, T., Zaucha, J., Swiatek, D. (2011). How to Strengthen the Territorial Dimension of "Europe 2020" and the EU Cohesion Policy. Warsaw.

Budde, R., Ehlert, C., Neumann, U., Peistrup, M., Grabow, B., Hollbach-Grömig, B., Bergs, R. (2010). Second State of European Cities Report. Essen. <https://ec.europa.eu/regional_policy/ sources/docgener/studies/pdf/urban/stateofcities_2010.pdf $>$.

Camagni, R., Capello, R., Caragliu, A. (2015). The rise of second-rank cities: what role for agglomeration economies? European Planning Studies 23(6): 1069-1089. doi:10.1080/09654313.20 14.904999

Castells-Quintana, D., Royuela, V. (2014). Agglomeration, inequality and economic growth. The Annals of Regional Science 52(2): 343-366. doi:10.1007/s00168-014-0589-1

Colini, L., Czischke, D., Güntner, S., Tosics, I., Ramsden, P. (2013). Against divided cities in Europe. Saint-Denis. <https://urbact.eu/sites/default/files/import/general_library/19765_Urbact_WS4_DIVIDED_low_FINAL.pdf $>$.

Dąbrowski, M. (2014). Engineering multilevel governance? Joint European support for Sustainable Investment in City Areas (JESSICA) and the involvement of private and financial actors in urban development policy. Regional Studies 48(12): 2006-2019. doi:10.1080/00343404.20 14.914625

${ }^{27}$ Idczak, Musiałkowska (2019); Musiałkowska, Idczak (2020). 
Duranton, G., Kerr, W. (2018). The Logic of Agglomeration, [in:] G.L. Clark, M.P. Feldman, M.S. Gertler, D. Wójcik (eds.), The New Oxford Handbook of Economic Geography. New York: Oxford University Press. doi:10.1093/oxfordhb/9780198755609.013.14

ESPON. (2012). Territorial Impact Assessment of Policies and EU Directives. Luxembourg.

Faludi, A. (2009). Territorial cohesion under the looking glass. Synthesis paper about the history of the concept and policy background to territorial cohesion. <https://ec.europa.eu/regional_policy/archive/consultation/terco/pdf/lookingglass.pdf>.

Fotino, F. (2014). The JESSICA Action in Italy 2007-2013. Bottlenecks, opportunities, and directions for the future. European Structural and Investment Funds Journal 2(3): 245-255. $<$ https://estif.lexxion.eu/article/ESTIF/2014/3/9>.

Glaeser, E.L. (2010). Agglomeration Economics. (E.L. Glaeser, Ed.). Chicago: University of Chicago Press.

Henderson, J.V. (2000). How Urban Concentration Affects Economic Growth. World Bank Policy Research Working Paper. <https://ssrn.com/abstract=630698>.

Idczak, P., Musiałkowska, I. (2019). The capacity of JESSICA Projects to repay loans based on own revenues. Entrepreneurial Business and Economics Review 7(2): 141-157. doi:10.15678/ EBER.2019.070208

Idczak, P., Musiałkowska, I., Mrozik, K. (2019). Zdolność projektów JESSICA do oddziaływania na procesy rynkowe w miastach. Biuletyn KPZK 273/274: 202-222.

Krugman, P. (1991). Increasing returns and economic geography. Journal of Political Economy 99(3): 483-499. doi:10.1086/261763

Medeiros, E. (2014). Territorial Impact Assessment (TIA). The Process, Methods, Techniques (ZOE | Dinâ). Lisbon: Centro de Estudos Geográficos.

Medeiros, E. (2016). Territorial cohesion: an EU concept. European Journal of Spatial Development 60: 1-30. <https://archive.nordregio.se/Global/EJSD/Refereed articles/refereed60.pdf>

Medeiros, E. (2019). Debating the urban dimension of territorial cohesion, [in:] E. Medeiros (ed.), Territorial Cohesion. The Urban Dimension (pp. 3-22). Bassel: Springer International Publishing. doi:10.1007/978-3-030-03386-6_1

Musiałkowska, I., Idczak, P. (2018). Is the JESSICA initiative truly repayable instrument? The Polish case study. Research Papers of Wrocław University of Economics 536: 143-151. doi:10.15611/pn.2018.536.13

Musiałkowska, I., Idczak, P. (2020). JESSICA initiative to support sustainable urban development projects in Poland, [in:] P. Idczak, I. Musiałkowska, O. Potluka (eds.), EU Cohesion Policy in Eastern and Southern Europe: Taking Stock and Drawing Lessons for the Future (pp. 169-200). Warsaw/Berlin: De Gruyter. doi:10.1515/9788395720451-009

Myrdal, G. (1957). Economic Theory and Under-Developed Regions. London: G. Duckworth.

Nadler, M., Nadler, C. (2018). Promoting investment in sustainable urban development with JESSICA: outcomes of a new EU policy initiative. Urban Studies 55(9): 1839-1858. doi:10.1177/0042098017702815

Nyikos, G. (2016). Financial Instruments in the 2014-20 Programming Period: First Experiences of Member States. Brussels: European Parliament, Policy Department B: Structural and Cohesion Policies. doi:10.2861/279642

Ramsden, P. (2011). Cities and Disadvantaged Neighbourhoods. <https://urbact.eu/sites/default/ files/import/general_library/Rapport_Urbact_II.pdf>.

Tosics, I. (2015). Integrated regeneration of deprived areas and the new cohesion policy approach. $<$ https://urbact.eu/sites/default/files/20150909_urbact_deprived-areas_gb_md_1.pdf>.

URBACT. (2010). J4C "Jessica For Cities". Working Group Guidelines Assessment and Criteria for "Jessicability" of Projects and Case Studies for the Application of "Jessica" Instrument. $<$ http://urbact.eu/sites/default/files/import/Projects/JESSICA_4_Cities/outputs_media/J4C_ Guidelines_Jessicability.pdf>.

URPofP. (2013). Urban Regeneration Programme for the city of Poznań - 3rd edition. <https:// www.poznan.pl $/ \mathrm{mim} / \mathrm{public} / \mathrm{main} /$ attachments.att? $\mathrm{co}=$ show\&instance $=1017 \&$ parent $=81623$ \&lang=pl\&id=238308>. 


\section{THE TERRITORIAL IMPACTS OF JESSICA PROJECTS IN MUNICIPALITIES: EVIDENCE FROM THE CITY OF POZNAŃ}

\section{Sum mary}

This paper sets out to explore the contribution of JESSICA projects to enhancing the territorial cohesion of urban areas. We apply a slightly modified TARGET_TIA methodology to assess the territorial impacts of those projects in the city of Poznań. It is found that the JESSICA projects brought about positive territorial effects in deprived urban areas, however, their impacts are quite varied. More exactly, the results demonstrate that projects which most closely addressed the specific needs of the particular urban areas make the greatest contribution to improving the territorial cohesion of a city. It is also suggested that the complexity of JESSICA projects should have a higher priority in granting a JESSICA loan.

Keywords: JESSICA initiative; territorial impact assessment; territorial cohesion; Poznań 
